\title{
Chemical changes in silver carp (Hypophthalmichthys molitrix) minced muscle during frozen storage: Effect of a previous washing process
}

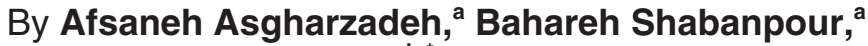 \\ Santiago P. Aubourg ${ }^{\text {b, }}$ and Hedayat Hosseini ${ }^{c}$ \\ a Fisheries Department, Agricultural and Natural Resources University, Gorgan, Iran. \\ ${ }^{b}$ Food Technology Department, Instituto de Investigaciones Marinas (CSIC), \\ c/ Eduardo Cabello, 6, 36208-Vigo, Spain. \\ ${ }^{\mathrm{c}}$ National Nutrition and Food Technology Research Institute, Tehran, Iran. \\ ( ${ }^{\star}$ Corresponding author: saubourg @iim.csic.es)
}

\section{RESUMEN}

Cambios químicos en músculo desmenuzado de carpa plateada (Hypophthalmichthys molitrix) durante su conservación en congelación: Efecto de un lavado previo

La carpa plateada (Hypophthalmichthys molitrix) ha adquirido un gran interés debido a su creciente producción acuícola y a su empleo en la elaboración de surimi. Este trabajo tiene como objetivo el estudio del efecto que sobre la calidad de músculo de carpa plateada desmenuzada puede tener un proceso de lavado seguido de conservación en congelación ( 6 meses; $\left.-18^{\circ} \mathrm{C}\right)$. Así, se observó un efecto positivo del lavado sobre la calidad de acuerdo con un descenso en los contenidos de humedad exprimible, aminas volátiles, ácidos grasos libres y sustancias reactivas con el ácido tiobarbitúrico; esta mejora de calidad se mantuvo durante la conservación en congelación. Asimismo, la mayoría de los índices de calidad estudiados reflejaron pérdidas de calidad durante la conservación en congelación independientemente del tratamiento previo; sin embargo, la capacidad de retención de agua permaneció invariable durante la congelación en pescado previamente lavado.

PALABRAS CLAVE: Acuicultura - Calidad - Carpa plateada - Congelación - Desmenuzado - Lavado - Surimi.

\section{SUMMARY}

Chemical changes in silver carp (Hypophthalmichthys molitrix) minced muscle during frozen storage: Effect of a previous washing process

Silver carp (Hypophthalmichthys molitrix) has acquired great attention because of its increasing farming production and application in the surimi-product commercialization. This work focuses on the effect of a washing process followed by frozen storage ( 6 months; $-18{ }^{\circ} \mathrm{C}$ ) on the quality of minced silver carp muscle. A previous washing step has led to a positive effect on fish quality according to marked content decreases in expressible moisture, volatile amines, free fatty acids and thiobarbituric acid reactive substances; such quality performances were maintained throughout the frozen storage. On the other hand, most indexes tested showed quality losses throughout the frozen storage in both washed and unwashed fish material; however, water holding capacity (WHC) remained unchanged in washed fish throughout the frozen storage. Among quality indexes, a special attention should be given to the expressible moisture value and accordingly the WHC, as being closely related to the gelforming ability in order to obtain surimi-type commercial products.

KEY-WORDS: Farming - Frozen storage - Mince Quality - Silver carp - Surimi - Washing.

\section{INTRODUCTION}

Fish species are known to provide high contents of important constituents for the human diet such as nutritional and readily-digestive proteins, lipid-soluble vitamins, microelements and polyunsaturated fatty acids (Friedman, 1996; Simopoulos, 1997). However, marine and fresh water products are known to easily deteriorate during post-mortem storage and processing as a result of different damage mechanisms such as autolytic degradation, microbiological spoilage and lipid oxidation (Whittle et al., 1990; Olafsdóttir et al., 1997).

Freezing and frozen storage are important methods for the preservation of fish species. Although many damage pathways are inhibited by such processes, undesirable reactions associated with lipids and proteins have shown to occur, leading to detrimental changes in nutritional and sensory properties (Sikorski and Kolakowska, 1994; Erickson, 1997). In this sense, cryoprotectants and antioxidants have been widely employed during frozen storage because of improving functional properties, avoiding lipid oxidation development, inhibiting dripping loss when defrosting, and prolonging shelf life time (Matsumoto and Nogochi, 1992; Pazos et al., 2005; SánchezAlonso et al., 2006).

In recent years, fish technologists and the fish trade have increasingly prompted more attention to aquaculture techniques as a source of fish and other seafood products (Stickney, 1990). Among cultivated fresh water fish, silver carp (Hypophthalmichthys molitrix) has acquired great attention because of its increasing production in countries like China, Bangladesh, India, Iran, and Russian Federation 
(FAO, 2007). Related to this fish species, previous research accounts for composition studies (Vujkovic et al., 1999; Roos et al., 2002), and its employment as a source of protein hydrolysates (Dong et al., 2008) and commercial products (Liu et al., 1991; Fan et al., 2008).

Among the different applications, silver carp has attracted great attention for use in the elaboration of surimi. Previous research concerning the gelforming capacity of this species has examined the effect of the catching season (Yuan et al., 2005) and the presence of different binding agents on gel-forming capacity (Uresti et al, 2004) as well as making comparisons to other fish species (Luo et al., 2001). The present work is focused on the chemical changes related to the quality loss of silver carp minced muscle during frozen storage. The effects of both a previous washing process and frozen storage time on different chemical (composition and quality indexes) parameters are studied.

\section{MATERIALS AND METHODS}

\subsection{Raw fish, processing and chemicals}

Silver carp (Hypophthalmichthys molitrix) (20 individuals; total weight $16.5 \mathrm{~kg}$ ) were obtained in January 2005 from North Local Farm (Babolsar, Iran) and transported in ice to a fish processing center (Kian Mahi Khazar; Babolsar, Iran). Individual fishes (weight range: $0.56-0.95 \mathrm{~kg}$ ) were gutted, dressed, filleted by hand and minced by employing a mechanical meat mincer with a $3 \mathrm{~mm}$-hole plate. Finally, $9.3 \mathrm{~kg}$ of minced fish muscle were obtained, one half left unwashed, while the other half was washed twice with distilled water and then twice with $0.3 \%$ aqueous $\mathrm{NaCl}$. Each washing stage was carried out for $15 \mathrm{~min}$ in an isothermal room at $4^{\circ} \mathrm{C}$ with a 4/1 ratio ( $\mathrm{v} / \mathrm{w}$, aqueous solution/ minced fish) (Luo et al., 2001). Washed minced fish muscle was then dewatered by hand with a low thickness cloth.

A cryoprotectant mixture was then added to unwashed and washed minces. This mixture consisted of sucrose ( $4 \% \mathrm{w} / \mathrm{w}$, sucrose/ minced fish), sorbitol (4\% w/w, sorbitol/ minced fish), and polyphosphate $(0.3 \% \mathrm{w} / \mathrm{w}$, polyphosphate/minced fish). Then, stabilized minces were packed (250g per bag) in high density polyethylene freezer bags and were frozen in an air blast system at $-35^{\circ} \mathrm{C}$ for $2 \mathrm{~h}$. The sample bags were then stored at $-18{ }^{\circ} \mathrm{C}$ for 6 months. Periodically (at months 0, 1, 2, 3, 4 and 6), bags corresponding to unwashed and washed treatments were taken and evaluated for chemical composition and quality loss. For both washed and unwashed minced fish, three different, independent batches $(n=3)$ were considered and studied separately throughout this study to achieve the statistical analysis.

Chemicals (solvents and reactants) employed throughout the study were reagent grade (E. Merck, Darmstadt, Germany).

\subsection{Proximate analyses}

Moisture content was determined by weight difference between the fresh homogenized muscle and the heated muscle according to the AOAC (2005a) method. Results were calculated as $\mathrm{g}$ water/ $100 \mathrm{~g}$ minced fish.

Lipids were extracted according to the Bligh and Dyer (1959) method. Lipid content was expressed as $\mathrm{g} / 100 \mathrm{~g}$ minced fish.

Total protein was measured by employing the Kjeldahl method according to the AOAC (2005b) method. Results were calculated as g protein/ $100 \mathrm{~g}$ minced fish.

\subsection{Quality analyses}

The water holding capacity (WHC) was determined according to the method of Suvanich et al. (2000). Expressible moisture was measured and results were calculated as $\mathrm{g}$ expressible moisture/ $100 \mathrm{~g}$ minced fish.

For the $\mathrm{pH}$ value assessment, $5 \mathrm{~g}$ of minced fish were homogenized for $1 \mathrm{~min}$ with $45 \mathrm{ml}$ of deionized water and then measured in a standardized automatic $\mathrm{pH}$ meter.

Total volatile base-nitrogen (TVB-N) content was analyzed according to the Parvaneh (1998) method. Results were expressed as mg TVB-N/ $100 \mathrm{~g}$ minced fish.

Free fatty acid (FFA) content was analyzed in the lipid extract according to the Egan et al. (1997) procedure. FFA content was calculated as $g$ oleic $\mathrm{acid} / 100 \mathrm{~g}$ lipids.

Peroxide value (PV) was determined in the lipid extract by the Egan et al. (1997) procedure. Results were calculated as meq active oxygen/ $\mathrm{kg}$ lipids.

The thiobarbituric acid index (TBA-i) was determined according to the method of Kirk and Sawyer (1991). Results were calculated as $\mu \mathrm{g}$ malondialdehyde/ $\mathrm{kg}$ minced fish.

\subsection{Statistical Analysis}

Data are expressed as mean values $(n=3)$ accompanied by the standard errors of means. Data from the different composition and quality parameters were subjected to one-way ANOVA $(p<0.05)$ by employing an SPSS software (version 11.5). Comparison of means after the ANOVA test was performed using the Duncan's multiple range test $(p<0.05)$.

\section{RESULTS AND DISCUSSION}

\subsection{Proximate analyses}

Results obtained from the proximate analysis are included in Tables 1-2. Table 1 shows data concerning minced muscle before the freezing step was carried 
Table 1

Proximate analysis of minced silver carp muscle before the freezing step*

\begin{tabular}{lccc}
\hline Minced Muscle & Moisture & Lipid & Protein \\
\hline Unwashed & $78.6 \mathrm{c}$ & $2.27 \mathrm{~b}$ & $16.5 \mathrm{~b}$ \\
Without cryoprotectant mixture & $(0.1)$ & $(0.04)$ & $(0.7)$ \\
Unwashed & $72.2 \mathrm{a}$ & $2.23 \mathrm{~b}$ & $16.4 \mathrm{~b}$ \\
With cryoprotectant mixture & $(0.2)$ & $(0.32)$ & $(0.3)$ \\
Washed & $82.4 \mathrm{~d}$ & $0.74 \mathrm{a}$ & $14.6 \mathrm{a}$ \\
Without cryoprotectant mixture & $(0.1)$ & $(0.10)$ & $(0.7)$ \\
Washed & $75.3 \mathrm{~b}$ & $0.75 \mathrm{a}$ & $15.0 \mathrm{a}$ \\
With cryoprotectant mixture & $(0.3)$ & $(0.19)$ & $(0.4)$ \\
\hline * Mean values (g/ 100g minced muscle) of three different determinations corresponding to \\
each fish batch considered ( $=3$ ), respectively. Standard errors of means are indicated in \\
brackets. For each parameter, mean values followed by different letters (a-d) denote significant \\
differences $(\mathrm{p}<0.05)$.
\end{tabular}

out, while Table 2 provides results related to the frozen storage period.

The moisture content of the starting raw fish (78.6 \pm 0.1 ; Table 1) was found higher than the one reported for a fatty fish species (sardine) (Aubourg et al., 1998), but lower than for a lean fish one (cod, haddock) (Aubourg and Medina, 1999), in accordance with an inverse ratio between moisture and lipid matter (Piclet, 1987). An important effect on the moisture content of minced fish could be observed as a result of washing. Thus, the removal of water-soluble compounds such as blood, pigments, proteins and salts may have led to an increasing hydration availability of the minced meat (Lin and Park, 1997) so that higher moisture values could be observed after the washing process whether the cryoprotectant mixture is added or not. On the other hand, for both the washed and unwashed fish material, the addition of the cryoprotectant mixture has led to a proportion decrease in the moisture content of the minced muscle. Throughout the frozen storage period (Table 2), higher moisture values $(p<0.05)$ were maintained for minced samples that were previously washed; further, a slight increase $(p<0.05)$ for both kinds of minced fish could be assessed at the end of the experiment.

The lipid content of the starting raw fish $(2.27 \pm 0.04$; Table 1$)$ agrees with previous research carried out on this species both coming from farmed and wild conditions (Kaneniwa et al., 2000; Siddaiah et al., 2001). This content is considered lower than for fatty fish species (sardine) (Aubourg et al., 1998), but higher than for a lean fish (cod, haddock) (Aubourg and Medina, 1999). A marked effect of washing could be observed on lipid content. Thus, fat content underwent an important decrease after washing that can be explained as a result of the minced material floating to the surface, leading to an increasing availability to be lost during such processing step (Babbit, 1986; Suvanich et al.,

Table 2

Evolution of chemical composition during the frozen storage of previously washed and unwashed minced silver carp*

\begin{tabular}{ccccccc}
\hline $\begin{array}{c}\text { Frozen } \\
\text { Storage Time } \\
\text { (months) }\end{array}$ & Unwashed & Washed & Unwashed & Washed & Unwashed & Washed \\
\cline { 2 - 7 } & $72.2 \mathrm{a}$ & $75.3 \mathrm{a}$ & 2.23 & 0.75 & 16.4 & $15.0 \mathrm{~b}$ \\
0 & $(0.2)$ & $(0.3)$ & $(0.32)$ & $(0.19)$ & $(0.3)$ & $(0.4)$ \\
& $72.4 \mathrm{ab}$ & $75.5 \mathrm{ab}$ & 2.08 & 0.90 & 16.3 & $14.4 \mathrm{ab}$ \\
1 & $(0.2)$ & $(0.3)$ & $(0.07)$ & $(0.14)$ & $(0.2)$ & $(0.3)$ \\
& $72.7 \mathrm{ab}$ & $75.8 \mathrm{ab}$ & 2.13 & 0.79 & 16.2 & $14.3 \mathrm{ab}$ \\
2 & $(0.1)$ & $(0.1)$ & $(0.01)$ & $(0.13)$ & $(0.2)$ & $(0.2)$ \\
& $72.8 \mathrm{ab}$ & $75.7 \mathrm{ab}$ & 2.12 & 0.78 & 14.6 & $13.7 \mathrm{ab}$ \\
3 & $(0.2)$ & $(0.3)$ & $(0.01)$ & $(0.12)$ & $(1.2)$ & $(0.9)$ \\
& $72.7 \mathrm{ab}$ & $75.5 \mathrm{ab}$ & 2.17 & 0.65 & 16.2 & $15.3 \mathrm{~b}$ \\
& $(0.2)$ & $(0.2)$ & $(0.06)$ & $(0.05)$ & $(0.2)$ & $(0.6)$ \\
& $72.8 \mathrm{~b}$ & $76.2 \mathrm{~b}$ & 1.93 & 0.69 & 16.3 & $11.5 \mathrm{a}$ \\
& $(0.1)$ & $(0.2)$ & $(0.16)$ & $(0.03)$ & $(0.5)$ & $(1.5)$ \\
\hline
\end{tabular}

* Mean values ( $\mathrm{g} / 100 \mathrm{~g}$ minced muscle) of three different determinations corresponding to each fish batch considered $(\mathrm{n}=3)$, respectively. Standard errors of means are indicated in brackets. For each parameter and for each kind of minced fish sample, mean values followed by different letters $(a-b)$ denote significant differences $(p<0.05)$ as a result of the frozen storage time (months). 
2000). This conclusion is valid for minced muscle whether the cryoprotectant mixture is added or not. Differences $(p<0.05)$ between both washed and unwashed minced samples were maintained throughout the frozen storage, so that a lower $(p<0.05)$ lipid content was present in previously washed muscle (Table 2). No effect $(p>0.05)$ of the frozen storage time could be observed for both kinds of minced fish on the lipid content.

Starting protein content for raw fish (16.5 \pm 0.7 ; Table 1) can be considered in the normal fish range (Piclet, 1987) and agrees with previous research concerning this species coming both from farming and wild conditions (Liu et al., 1991; Siddaiah et al., 2001). A significant decrease in the protein content was observed as a result of washing whether the cryoprotectant mixture is added or not. This lower value $(p<0.05)$ was then maintained throughout the frozen storage period in washed fish (Table 2). This content decrease produced during the washing process can be easily explained by means of partial solubilization of the sarcoplasmic protein into the washing material (Mackie, 1993; Sikorski and Kolakowska, 1994). As a result of the frozen storage, a protein content decrease was obtained at the end of the experiment for previously washed samples; however, no differences $(p>0.05)$ during frozen storage could be outlined for unwashed samples.

\subsection{Expressible moisture value}

According to the starting raw mince value $(20.9 \pm 0.2$; Table 3$)$, a decrease $(p<0.05)$ in the expressible moisture value could be interpreted as a result of the previous washing stage $(15.0 \pm 0.5$; Table
3). Throughout the frozen storage, this higher value $(p<0.05)$ for unwashed minced fish was maintained when compared to its counterpart washed fish. Accordingly, a profitable effect of previous washing could be attributed to minced silver carp since a higher WHC was obtained, leading to a better gelforming ability (Uresti et al., 2004; Sánchez-Alonso et al., 2006). This result can be explained by the higher proportion of myofibrillar proteins present in washed fish and agrees with previous results where, WHC has shown to depend on the physicochemical properties of proteins such as hydrophobicity, solubility and dispersion capacity (Matsumoto and Nogochi, 1992; Sikorski and Kolakowska, 1994). The expressible moisture content of unwashed silver carp mince increased considerably during the frozen storage time. This indicated that less water was imbibed in the gel matrix as a result of a protein denaturation increase by extended frozen storage leading to a lower water affinity and accordingly, to a WHC decrease (Reddy and Srikar, 1991; Visessanguan et al., 2005).

\subsection{Assessment of $\mathrm{pH}$ and TVB-N}

A marked effect of washing could be observed in $\mathrm{pH}$ value (Table 3$)$, since lower $(\mathrm{p}<0.05)$ values were obtained for unwashed samples; this difference was maintained after the freezing step and throughout the frozen storage period. This result could be explained as a result of a partial removal of water-soluble acid substances such as acid free amino acids, lactic acid, FFA and so on. However, pH profiles for both unwashed and washed silver carp minces did not show significant changes $(p>0.05)$ as a result of the frozen storage time.

Table 3

Evolution of different quality parameters* during the frozen storage of previously washed and unwashed minced silver carp ${ }^{\star *}$

\begin{tabular}{|c|c|c|c|c|c|c|}
\hline \multirow{2}{*}{$\begin{array}{l}\text { Frozen } \\
\text { Storage Time } \\
\text { (months) }\end{array}$} & \multicolumn{2}{|c|}{$\begin{array}{l}\text { Expressible Moisture } \\
\text { (g/ 100g muscle) }\end{array}$} & \multicolumn{2}{|c|}{$\mathrm{pH}$} & \multicolumn{2}{|c|}{$\begin{array}{c}\text { TVB-N } \\
\text { (mg/ 100g muscle) }\end{array}$} \\
\hline & Unwashed & Washed & Unwashed & Washed & Unwashed & Washed \\
\hline 0 & $\begin{array}{c}20.8 \mathrm{a} \\
(0.2)\end{array}$ & $\begin{array}{c}15.2 \mathrm{ab} \\
(1.0)\end{array}$ & $\begin{array}{c}7.0 \\
(0.1)\end{array}$ & $\begin{array}{c}7.8 \\
(0.1)\end{array}$ & $\begin{array}{c}13.2 \mathrm{a} \\
(0.4)\end{array}$ & $\begin{array}{c}5.8 \mathrm{ab} \\
(0.2)\end{array}$ \\
\hline 1 & $\begin{array}{c}24.8 \mathrm{~b} \\
(1.1)\end{array}$ & $\begin{array}{c}15.0 \mathrm{a} \\
(0.5)\end{array}$ & $\begin{array}{c}7.1 \\
(0.1)\end{array}$ & $\begin{array}{c}7.7 \\
(0.1)\end{array}$ & $\begin{array}{c}13.2 \mathrm{ab} \\
(0.6)\end{array}$ & $\begin{array}{c}5.6 \mathrm{ab} \\
(0.2)\end{array}$ \\
\hline 2 & $\begin{array}{c}26.5 \mathrm{bc} \\
(0.8)\end{array}$ & $\begin{array}{c}15.0 \mathrm{a} \\
(0.5)\end{array}$ & $\begin{array}{c}7.1 \\
(0.1)\end{array}$ & $\begin{array}{l}7.8 \\
(0.1)\end{array}$ & $\begin{array}{c}14.9 \mathrm{ab} \\
(0.4)\end{array}$ & $\begin{array}{l}4.9 \mathrm{a} \\
(0.3)\end{array}$ \\
\hline 3 & $\begin{array}{l}28.9 \mathrm{bcd} \\
(1.3)\end{array}$ & $\begin{array}{c}14.9 \mathrm{a} \\
(0.6)\end{array}$ & $\begin{array}{l}7.1 \\
(0.1)\end{array}$ & $\begin{array}{c}7.9 \\
(0.1)\end{array}$ & $\begin{array}{c}14.9 \mathrm{ab} \\
(0.6)\end{array}$ & $\begin{array}{c}5.6 \mathrm{ab} \\
(0.2)\end{array}$ \\
\hline 4 & $\begin{array}{l}29.2 \mathrm{~cd} \\
(0.9)\end{array}$ & $\begin{array}{c}17.0 \mathrm{ab} \\
(0.7)\end{array}$ & $\begin{array}{l}7.1 \\
(0.1)\end{array}$ & $\begin{array}{l}7.8 \\
(0.1)\end{array}$ & $\begin{array}{l}15.0 \mathrm{~b} \\
(0.5)\end{array}$ & $\begin{array}{l}6.2 \mathrm{bc} \\
(0.2)\end{array}$ \\
\hline 6 & $\begin{array}{c}29.4 d \\
(0.6)\end{array}$ & $\begin{array}{c}17.6 \mathrm{~b} \\
(0.8)\end{array}$ & $\begin{array}{c}7.0 \\
(0.1)\end{array}$ & $\begin{array}{c}7.8 \\
(0.1)\end{array}$ & $\begin{array}{c}17.6 \mathrm{c} \\
(0.5)\end{array}$ & $\begin{array}{l}7.3 c \\
(0.3)\end{array}$ \\
\hline
\end{tabular}

* Mean values of three different determinations corresponding to each fish batch considered $(n=3)$, respectively. Standard errors of means are indicated in brackets. For each parameter and for each kind of minced fish sample, mean values followed by different letters (a-d) denote significant differences $(p<0.05)$ as a result of the frozen storage time.

${ }^{* *}$ Abbreviation employed: TVB-N (total volatile base-nitrogen). Starting unwashed minced fish values: $20.9 \pm 0.2$ (expressible moisture), $7.0 \pm 0.1(\mathrm{pH})$, and $12.7 \pm 0.3($ TVB-N). Starting washed minced fish values: $15.0 \pm 0.5$ (expressible moisture), $7.7 \pm 0.1(\mathrm{pH})$ and $5.9 \pm 0.2($ TVB-N). 
Concerning the TVB-N value (Table 3), the washing process has led to a remarkably lower $(p<0.05)$ content, according to values obtained before and after such treatment $(12.7 \pm 0.3$ and $5.9 \pm 0.2$, respectively); additionally, higher values $(p<0.05)$ for previously unwashed fish were maintained throughout the frozen storage. Lower TVB-N values in washed mince can be explained as a result of a partial removal of $\mathrm{N}$-containing molecules susceptible to breakdown during the washing step, leading to volatile and basic compounds. Both kinds of fish material showed a TVB-N content increase at the end of the experiment, according to previous research on frozen minced fish (Vareltzis et al., 1997; Suvanich et al., 2000). This increase can be explained as a result of the breakdown of endogenous compounds into non-protein $\mathrm{N}$-compounds.

It has been stated that TVB-N content should be considered a very unreliable indicator of frozen storage quality loss (Kyrana et al., 1997). It has even been reported that it could be used in frozen fish as an indicator of starting fish quality before the freezing step is accomplished since no TVB-N content change during frozen storage would be expected to occur (Moral-Rama, 1987). However, and according to the present results, previous studies account for a TVB-N content increase during the frozen storage of minced muscle (Vareltzis et al., 1997; Siddaiah et al., 2001).

\subsection{Lipid hydrolysis development}

Raw starting values of FFA content (Table 4) can be considered in the range of those reported for fresh lean fish species (Aubourg and Medina, 1999), while FFA proportion has been found to be much lower in fresh fatty fish species (Aubourg et al., 1998). In the present experiment, the previous washing process has led to a FFA content decrease $(p<0.05)$ according to values observed before and after such treatment $(10.3 \pm 0.3$ and $7.4 \pm 0.4$, respectively; Table 4). This result can be explained as a result of partially dissolving the FFA compounds and agrees with the $\mathrm{pH}$ value assessment (Table 3 ), where a $\mathrm{pH}$ increase was obtained as a result of washing. In addition, a lower FFA content $(p<0.05)$ in previously washed minced silver carp was maintained throughout the frozen storage time when compared to its counterpart unwashed fish. Further, the frozen storage has led to a marked FFA increase with time in both kinds of minced material that can be explained as a result of hydrolytic enzymes present in minced silver carp muscle, which remain active during frozen storage at $-18{ }^{\circ} \mathrm{C}$ (Kaneniwa et al., 2000; Sikorski and Kolakowski, 2000).

While the formation of FFA itself does not lead to nutritional losses, its assessment is deemed important when considering the development of rancidity. Thus, a pro-oxidant effect of FFA on lipid matter has been proposed and explained on the basis of a catalytic effect of the carboxyl group on the formation of free radicals by the decomposition of hydroperoxides (Yoshida et al., 1992; Aubourg, 2001). In addition, FFA has shown to interact with proteins leading to fish texture deterioration during frozen storage (Mackie, 1993).

\subsection{Lipid oxidation development}

Rancidity development was measured by means of primary (PV) and secondary (TBA-i) lipid oxidation compound formation (Table 4).

Table 4

Evolution of different lipid damage indexes* during the frozen storage of previously washed and unwashed minced silver carp ${ }^{\star \star}$

\begin{tabular}{|c|c|c|c|c|c|c|}
\hline \multirow{2}{*}{$\begin{array}{c}\text { Frozen } \\
\text { Storage Time } \\
\text { (months) }\end{array}$} & \multicolumn{2}{|c|}{ Free fatty acids (FFA) } & \multicolumn{2}{|c|}{ Peroxide Value (PV) } & \multicolumn{2}{|c|}{$\begin{array}{c}\text { Thiobarbituric Acid Index } \\
\text { (TBA-i) }\end{array}$} \\
\hline & Unwashed & Washed & Unwashed & Washed & Unwashed & Washed \\
\hline 0 & $\begin{array}{l}9.7 \mathrm{a} \\
(0.2)\end{array}$ & $\begin{array}{l}6.6 \mathrm{a} \\
(0.2)\end{array}$ & $\begin{array}{l}1.3 \mathrm{a} \\
(0.0)\end{array}$ & $\begin{array}{l}1.1 \mathrm{a} \\
(0.2)\end{array}$ & $\begin{array}{c}23.0 \mathrm{a} \\
(1.4)\end{array}$ & $\begin{array}{l}2.0 \mathrm{a} \\
(0.6)\end{array}$ \\
\hline 1 & $\begin{array}{c}11.8 \mathrm{~b} \\
(0.5)\end{array}$ & $\begin{array}{l}7.6 \mathrm{~b} \\
(0.1)\end{array}$ & - & - & $\begin{array}{c}26.0 \mathrm{a} \\
(0.9)\end{array}$ & $\begin{array}{c}2.6 \mathrm{a} \\
(0.9)\end{array}$ \\
\hline 2 & $\begin{array}{c}14.0 \mathrm{c} \\
(0.2)\end{array}$ & $\begin{array}{c}10.2 \mathrm{c} \\
(0.2)\end{array}$ & $\begin{array}{l}5.0 \mathrm{~b} \\
(0.2)\end{array}$ & $\begin{array}{l}2.1 \mathrm{~b} \\
(0.3)\end{array}$ & $\begin{array}{c}28.0 \mathrm{a} \\
(1.2)\end{array}$ & $\begin{array}{c}5.0 \mathrm{ab} \\
(1.4)\end{array}$ \\
\hline 3 & $\begin{array}{l}14.7 \mathrm{~d} \\
(0.1)\end{array}$ & $\begin{array}{l}11.6 \mathrm{~d} \\
(0.4)\end{array}$ & - & - & $\begin{array}{l}47.0 \mathrm{~b} \\
(8.1)\end{array}$ & $\begin{array}{l}13.0 \mathrm{c} \\
(2.9)\end{array}$ \\
\hline 4 & $\begin{array}{l}14.8 \mathrm{~d} \\
(0.1)\end{array}$ & $\begin{array}{c}13.6 \mathrm{e} \\
(0.3)\end{array}$ & - & - & $\begin{array}{c}30.0 \mathrm{a} \\
(4.6)\end{array}$ & $\begin{array}{l}10.0 \mathrm{bc} \\
(2.9)\end{array}$ \\
\hline 6 & $\begin{array}{c}15.1 \mathrm{e} \\
(0.2)\end{array}$ & $\begin{array}{c}14.1 \mathrm{e} \\
(0.3)\end{array}$ & $\begin{array}{c}10.2 c \\
(0.3)\end{array}$ & $\begin{array}{l}7.1 \mathrm{c} \\
(0.2)\end{array}$ & $\begin{array}{c}26.0 \mathrm{a} \\
(1.4)\end{array}$ & $\begin{array}{c}7.5 \mathrm{bc} \\
(0.4)\end{array}$ \\
\hline
\end{tabular}

* Mean values of three different determinations corresponding to each fish batch considered $(n=3)$, respectively. Standard errors of means are indicated in brackets. For each parameter and for each kind of minced fish sample, mean values followed by different letters (a-e) denote significant differences $(p<0.05)$ as a result of the frozen storage time.

** Data expressed as: $\mathrm{g} / 100 \mathrm{~g}$ lipids (FFA), meq active oxygen/ kg lipids (PV) and $\mu \mathrm{g}$ malondialdehyde/ kg muscle (TBA-i). Starting unwashed minced fish values: $10.3 \pm 0.3$ (FFA), $1.4 \pm 0.1$ (PV) and $23.2 \pm 1.0$ (TBA-i). Starting washed minced fish values: $7.4 \pm 0.4$ (FFA), $1.3 \pm 0.1(\mathrm{PV})$ and $1.9 \pm 0.5(\mathrm{TBA}-\mathrm{i})$ 
Starting raw fish showed a low PV $(1.4 \pm 0.1)$ that remained unchanged after the washing process and the freezing step (month 0 value). However, a marked peroxide content increase could be observed for both kinds of minced materials at the end of the frozen storage. This could be explained as a result of the presence of pro-oxidant enzymes (lipoxygenases, peroxidases, and so on) and chemical pro-oxidant molecules (namely, hemoproteins and metal ions) (Erickson, 1997; Sikorski and Kolakowski, 2000). Values were, however, lower $(p<0.05)$ for the washed material (months 2 and 6) according to the washing effect that partially eliminates such oxidation catalyzers (Richards and Hultin, 2002; Undeland et al., 1998). This washing effect agrees with previous research where an important oxidation inhibition on frozen fish samples was obtained by apreliminary water soaking that was followed by frozen storage (Richards et al., 1998; Aubourg et al., 2004).

Concerning the secondary lipid oxidation assessment, the TBA provided an important decrease as a result of washing (Table 4), showing a higher $(p<0.05)$ oxidation stage in the unwashed material before undergoing the freezing step. This higher TBA-i $(p<0.05)$ for unwashed minced fish was maintained throughout the frozen storage time when compared to its counterpart washed fish. For both kinds of minced fish, a clear tendency could not be concluded throughout the frozen storage time, with the highest mean value attained at month 3 .

\section{CONCLUSIONS}

Washing, along with the removal of fat, blood, pigments, enzymes and other water-soluble undesirable compounds resulted in marked chemical changes in minced silver carp muscle. As a result, an important positive effect on minced fish quality could be assessed due to marked content decreases in expressible moisture, TVB-N, FFA and thiobarbituric acid reactive substances. Such quality differences in washed minced fish were maintained throughout the frozen storage period $\left(-18^{\circ} \mathrm{C}\right)$ up to six months. On the other hand, most indexes checked (TVB-N, FFA and PV) showed quality losses throughout frozen storage both in washed and unwashed fish material; however, in the case of WHC, only unwashed minced muscle provided a quality decrease.

Among quality indexes, special attention should be paid to the expressible moisture value and accordingly, the WHC as being closely related to the gel-forming ability to obtain surimi-type commercial products.

\section{ACKNOWLEDGEMENTS}

Authors would like to express their sincere acknowledge to the Food and Drug Control Laboratory (FDCL; Tehran, Iran), especially to the Meat and Protein Department for supporting this study. Mr. Niksirat, Mrs. Booshehri and Mrs. Abbasi are also gratefully acknowledged for their technical assistance.

\section{REFERENCES}

AOAC. 2005a. Official methods of analysis of the Association of Analytical Chemistry, $18^{\text {th }}$ ed., chapter 39, p. 1 (code 39.1.01). Association of Official Analytical Chemists, Washington DC, USA.

AOAC. 2005b. Official methods of analysis of the Association of Analytical Chemistry, $18^{\text {th }}$ ed., chapter 39, pp. 5-8 (code 39.1.15). Association of Official Analytical Chemists, Washington DC, USA.

Aubourg S. 2001. Fluorescence study of the pro-oxidant effect of free fatty acids on marine lipids. J. Sci. Food Agric. 81, 385-390.

Aubourg S, Lugasi A, Hóvári J, Piñeiro C, Lebovics V, Jakóczi I. 2004. Damage inhibition during frozen storage of horse mackerel (Trachurus trachurus) fillets by a previous plant extract treatment. J. Food Sci. 69, 136-141.

Aubourg S, Medina I. 1999. Influence of storage time on lipid deterioration during cod (Gadus morhua) and haddock (Melanogrammus aeglefinus) frozen storage. J. Food Sci. 79, 1943 -1948.

Aubourg S, Sotelo C, Pérez-Martín R. 1998. Assessment of quality changes in frozen sardine (Sardina pilchardus) by fluorescence detection. J. Amer. Oil Chem. Soc. 75, 575-580.

Babbit J. 1986. Suitability of fish species as raw material. Food Technol. 40, 97-100, 134.

Bligh E, Dyer W. 1959. A rapid method of total extraction and purification. Can. J. Biochem. Physiol. 37, 911917.

Dong S, Zeng M, Wang D, Liu Z, Zao Y, Yang $\mathrm{H}$. 2008. Antioxidant and biochemical properties of protein hydrolysates prepared from silver carp (Hypophthalmichthys molitrix). Food Chem. 10, 14851493.

Egan H, Kirk R, Sawyer R. 1997. Pearson's Chemical Analysis of Foods, $9^{\text {th }}$ ed., pp. 609-634. Churchill Livingstone, Edinburgh, Scotland, UK.

Erickson M. 1997. Lipid oxidation: Flavor and nutritional quality deterioration in frozen foods in Erickson M, Hung Y (Eds.) Quality in frozen food, pp. 141-173. Chapman and Hall, New York, USA.

Fan W, Chi Y, Zhang S. 2008. The use of a tea polyphenol dip to extend the shelf life of silver carp (Hypophthalmichthys molitrix) during storage in ice. Food Chem. 108, 148-153.

FAO. 2007. Fishery statistics. Aquaculture production. In Food and Agriculture Organization of the United Nations, Yearbook 2005, Vol 100/2, pp. 55-56, Rome, Italy.

Friedman M. 1996. Nutritional value of proteins from different food sources. J. Agric. Food Chem. 44, 6-29.

Kaneniwa M, Miao S, Yuan C, lida H, Fukuda Y. 2000. Lipid components and enzymatic hydrolysis of lipids in muscle of Chinese freshwater fish. J. Amer. Oil Chem. Soc. 77, 825-831.

Kirk R, Sawyer R. 1991. Pearson's Composition and Analysis of Foods, $9^{\text {th }}$ ed., pp. 642-643. Longman Scientific and Technical, Singapore, Singapore.

Kyrana W, Laugovois V, Valsamis D. 1997. Assessment of shelf-life of maricultured gilthead sea bream (Sparus aurata) stored in ice. Int. J. Food Sci. Technol. 32, 339-347.

Lin T, Park J. 1997. Effective washing condition reduce water usage for surimi processing. J. Aquat. Food Prod. Technol. 6, 65-79. 
Liu M, Chen R, Tsai M, Yang J. 1991. Effect of gamma irradiation on the keeping quality and nutrients of tilapia (Oreochromis mossambicus) and silver carp (Hypophthalmichthys molitrix) stored at $1^{\circ} \mathrm{C}$. J. Sci. Food Agric. 57, 555-563.

Luo U, Kuwahara R, Kaneniwa M, Murata Y, Yokoyama M. 2001. Comparison of gel properties of surimi from Alaska pollack and three freshwater fish species: effects of thermal processing and protein concentration. $J$. Food Eng. Phys. Propert. 66, 548-554.

Mackie I. 1993. The effects of freezing on flesh proteins. Food Rev. Intern. 9, 575-610.

Matsumoto J, Nogochi S. 1992. Cryostabilization of protein in surimi in Lanier T, Lee C (Eds.) Surimi Technology, pp. 357-388. Marcel Dekker, Inc., New York, USA.

Moral-Rama A. 1987. Physical and chemical methods for quality control in fish. Alimentación: Equipos y Tecnología, 3, 115-122.

Olafsdóttir G, Martinsdóttir E, Oehlenschläger J, Dalgaard $P$, Jensen B, Undeland I, Mackie I, Henehan G, Nielsen $\mathrm{J}$, Nilsen H. 1997. Methods to evaluate fish freshness in research and industry. Trends Food Sci. Technol. 8, 258-265.

Parvaneh V. 1998. Quality control and chemical analysis of food, pp. 250-251. Tehran University Publications, Tehran, Iran.

Pazos M, Gallardo J, Torres J, Medina I. 2005. Activity of grape polyphenol as inhibitors of the oxidation of fish lipids and frozen fish muscle. Food Chem. 92, 547557.

Piclet G. 1987. Le poisson aliment. Composition et intérêt nutritionnel. Cah. Nutr. Diét. XXII, 317-335.

Reddy G, Srikar L. 1991. Preprocessing ice storage effects on functional properties of fish mince protein. J. Food Sci. 56, 965-968.

Richards M, Hultin H. 2002. Contributions of blood and blood components to lipid oxidation in fish muscle. $J$. Agric. Food Chem. 50, 555-564.

Richards M, Kelleher S, Hultin H. 1998. Effect of washing with or without antioxidants on quality retention of mackerel fillets during refrigerated and frozen storage. J. Agric. Food Chem. 46, 4363-4371.

Roos N, Leth T, Jakobsen J, Haraksingh Thilsted S. 2002. High vitamin A content in some small fish species in Bangladesh: perspective for food-based strategies to reduce vitamin A deficiency. Int. J. Food Sci. Technol. 53, 425-437.

Sánchez-Alonso I, Haji-Maleki R, Borderías J. 2006. Effect of wheat fibre in frozen storage fish muscular gels. Eur. Food Res. Technol. 223, 571-576.

Siddaiah D, Vidya Sagar Redy G, Raju C, Chandrasekhar T. 2001. Changes in lipids, proteins and kamaboko forming ability of silver carp (Hypophthalmichthys molitrix) mince during frozen storage. Food Res. Intern. 34, 47-53.

Sikorski Z, Kolakowski E. 2000. Endogenous enzyme activity and seafood quality: Influence of chilling, freezing, and other environmental factors in Haard N, Simpson B (Eds.) Seafood enzymes, pp. 451-487. Marcel Dekker, New York, USA.

Sikorski Z, Kolakowska A. 1994. Changes in protein in frozen stored fish in Sikorski Z, Sun Pan B (Eds.) Seafood proteins, pp. 99-112. Chapman and Hall, New York, USA.

Simopoulos A. 1997. Nutritional aspects of fish in Luten J, Börrensen T, Oehlenschläger J (Eds.) Seafood from producer to consumer, Integrated Approach to Quality, pp. 589-607. Elsevier Science, London, UK.

Stickney R. 1990. A global overview of aquaculture production. Food Rev. Intern. 6, 299-315.

Suvanich V, Jahncke M, Marshall D. 2000. Changes in selected chemical quality characteristics of Channel catfish frame mince during chill and frozen storage. $J$. Food Sci. 65, 24-29.

Undeland I, Ekstrand B, Lingnert H. 1998. Lipid oxidation in minced herring (Clupea harengus) during frozen storage. Effect of washing and precooking. J. Agric. Food Chem. 46, 2319-2328.

Uresti R, Téllez-Luis S, Ramírez J, Vázquez M. 2004. Use of diary proteins and microbial transglutaminase to obtain low-salt fish products from filleting waste from silver carp (Hypophthalmichthys molitrix). Food Chem. 86, 257-262.

Vareltzis K, Koufidis D, Gravilidou E, Papavergou E, Vasiliadou S. 1997. Effectiveness of a natural rosemary (Rosmarinus officinalis) extract on the stability of filleted and minced fish during frozen storage. Zeitsch. Lebensm. Unters. Forsch. 205, 93-96.

Visessanguan W, Chutima T, Munehiko T. 2005. Effect of frozen storage on chemical and gel-forming properties of fish commonly used for surimi production in Thailand. Food Hydrocol. 19, 197-207.

Vujkovic G, Karlovic D, Vujkovic I, Vörösbatranyi I, Jovanovic B. 1999. Composition of muscle tissue lipids of silver carp and bighead carp. J. Amer. Oil Chem. Soc. 76, 475-480.

Whittle K, Hardy R, Hobbs G. 1990. Chilled fish and fishery products in Gormley T. (Ed.) Chilled foods: The state of the art, pp. 87-116. Elsevier Applied Science, New York, USA.

Yoshida H, Kondo I, Kajimoto G. 1992. Participation of free fatty acids in the oxidation of purified soybean oil during microwave heating. J. Amer. Oil Chem. Soc. 69, 1136-1140.

Yuan C, Fukuda Y, Kaneniwa M, Chen S, Cheng Y, Wang X, Konno K. 2005. Comparison of gel-forming properties of silver carp (Hypophthalmichthys molitrix) surimi prepared in different seasons. J. Food Sci. 70, C326-C331. 